\title{
ADOPSI INOVASI USAHA KECIL DAN MENENGAH (UKM) DI SURAKARTA TERHADAP SISTEM PERBANKAN SYARIAH
}

\author{
Kussudyarsana \\ Fakultas Ekonomi Universitas Muhammadiyah Surakarta \\ Jalan A. Yani Tromol Pos I Pabelan Surakarta Jawa Tengah 57102. Telepon: +62271717417 psw 229
}

Diterima 8 September 2009/ Disetujui 2 April 2010

\begin{abstract}
This article tries to explain the adoption innovation phenomenon of sharia banking in Surakarta, especially for small-scale enterprises in Surakarta. This paper tries to investigate some factors that are predicted stimulate the owners of small enterprises to adopt or not to adopt the sharia banking. Those factors were principle of religion about interest, profit sharing, financial risk, cost of fund and banking facility. Research suggests that there were no significant impact of all factors except profit sharing. To measure how they would adapt we tested by several factors of Rogers model such as relative advantage, compatibility, complexity, trialibility, and observability. The result showed that this innovation could be having a relative advantage and compatibility, had a significant effect on the adoption of innovation but not for three others factors. To test the hypothesis we use regression analysis, cross tabulation and chi-square statistic.
\end{abstract}

Keywords: adoption innovation, compatibility, complexity, triability, observability

\begin{abstract}
Abstrak: Artikel ini bertujuan menjelaskan fenomena inovasi dalam penerapan perbankan syariah di Surakarta, terutama usaha kecil di Surakarta. Tulisan ini mencoba menyelidiki beberapa faktor yang diharapkan akan mendorong pemilik usaha kecil untuk mengadopsi atau tidak mengadopsi perbankan syariah. Beberapa faktor tersebut telah menjadi agama prinsip bunga, bagi hasil, resiko keuangan, biaya dana dan fasilitas perbankan. Penelitian menunjukkan bahwa tidak ada dampak signifikan dari semua faktor kecuali bagi hasil/keuntungan. Untuk mengukur bagaimana mereka akan beradaptasi kami menguji beberapa faktor dari model Rogers seperti keuntungan relatif, kompatibilitas, kompleksitas, triabilitas, dan observabilitas. Hasil penelitian menunjukkan bahwa inovasi ini memiliki keuntungan relatif dan kompatibilitas, memiliki pengaruh signifikan pada adopsi inovasi tetapi tidak untuk tiga faktor lainnya. Hypothesis testing is used regression analysis, cross tabulation, and chi-square statistic.
\end{abstract}

Kata kunci: adoption innovation, kompatibilitas, kompleksitas, triabilitas, observability

\section{PENDAHULUAN}

Pada saat ini di Indonesia telah berkembang sistem perbankan syariah di samping sistem perbankan konvensional. Sistem Syariah secara resmi diterapkan pertama kali pada tahun 1992 ketika berdiri Bank Muamalah Indonesia. Sistem ini semakin berkembang sejak adanya UU No 10 Tahun 1998 tentang perbankan yang mengakui keberadaan bank konvensional dan bank syariah secara berdampingan atau dikenal dual banking system. Hal ini juga didukung oleh ketentuan Bank Indonesia mengenai kelembagaan dan jaringan kantor bank bagi bank umum syariah (BUS), bank umum konvensional (BUK) yang membuka unit usaha syariah (UUS) dan serta ketentuan bagi BPR syariah (BPRS).

Apabila dilihat dari pertumbuhan jumlah bank maka terlihat pertumbuhan yang cukup 

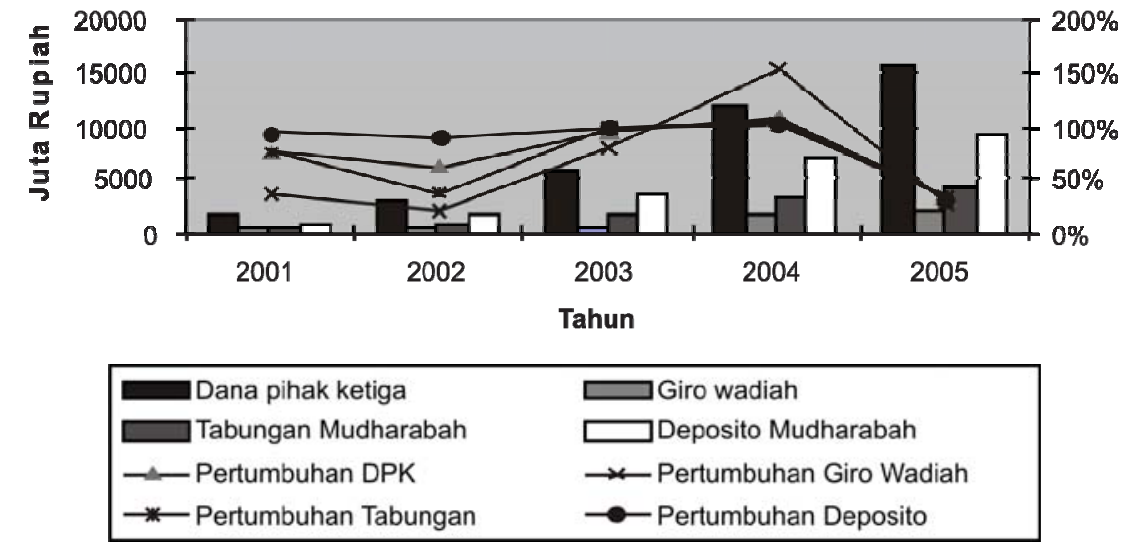

Sumber: Kompas, 2007

Gambar 1. Pertumbuhan Dana Pihak Ketiga

pesat, khususnya pada kelompok BUS dan UUS dimana dalam kurun waktu 5 tahun, mulai dari tahun 2000 hingga 2005 jumlah total BUS dan UUS sudah mencapai 504. Adapun jumlah bank umum syariah hanya 3 buah dan jumlah BPRS adalah 92. Namun apabila dilihat dari pertumbuhan dana pihak ketiga setiap tahun yang mengalami fluktuasi.

Kondisi tersebut terlihat jelas pada Gambar 1, dimana pada tahun 2001 sampai 2002 mengalami pertumbuhan yang menurun. Sedangkan pada tahun 2002 sampai tahun 2004 dana pihak ketiga mengalami pertumbuhan yang meningkat tajam, dimana giro wadiah (154 persen), tabungan mudharabah (103 persen) dan deposito mudharabah (103 persen). Namun pada akhir tahun 2005 pertumbuhan dana pihak ketiga mengalami penurunan kembali, dimana giro wadiah (26 persen), tabungan mudharabah (34 persen) dan deposito mudharabah (31 persen).

Dibandingkan bank konvensional, asset bank syariah masih jauh tertinggal. asset bank syariah pada akhir 2005 mencapai Rp20,9 triliun atau sekitar 1,42 persen dari total perbankan nasional. Asset bank syariah pada tahun 2006, adalah 1,5 persen dari total pangsa pasar perbankan. sementara itu, pembiayaan sebesar 2,19 persen dari total pembiayaan perbankan nasional. Jumlah tersebut terhitung kecil, mengingat mayoritas penduduk Indonesia adalah muslim. Jumlah asset yang kecil dibandingkan bank konvensional, tidak terlepas dari posisinya sebagai produk baru di mata masyarakat perbankan Indonesia.
Perkembangan bank syariah diperkirakan akan semakin cepat manakala masyarakat termasuk dalam hal ini UKM secara cepat mengadopsi sistem syariah sebagai pilihan perbankan. Kerjasama yang erat antara sektor perbankan dalam hal ini perbankan syariah dan UKM sangat diperlukan. Hasil penelitian kerjasama Kementrian KUKM dan BPS (2003) menunjukkan bukti bahwa 51,09 persenUKM mengalami kesulitan usaha yang disebabkan oleh masalah permodalan. Hasil selanjutnya memberikan fakta bahwa hanya 17,50 persen UKM yang mengatasi masalah permodalan dengan kredit perbankan, sedangkan sisanya (82,50 persen) dengan pendanaan informal (informal lender). Alasan-alasan yang menyebabkan UKM tidak meminjam ke bank adalah prosedur sulit (330,30 persen), tidak berminat (25,34 persen), tidak punya agunan (19,28 persen), tidak tahu prosedur (14,33 persen),suku bunga tinggi (8,82 persen) dan proposal ditolak (11,93 persen). Sangat ironis sekali bahwa di tengah kondisi excess suplai pasar kredit di Indonesia sekalipun, perkembangan sektor UKM justru terhambat karena masalah kekurangan permodalan terutama dari perbankan.

Antonio dan Subarjo (1999) menyatakan bahwa rendahnya pengetahuan masyarakat terhadap perbankan menjadi kendala perkembangan bank syariah. Suatu produk baru, inovasi, sistem baru, biasanya tidak langsung diterima masyarakat Suatu inovasi memerlukan waktu untuk diadopsi oleh individu ataupun sekelompok masyarakat (Rogers, 1995). Hal ini 
berarti merubah mindset dan cara belajar masyarakat dari yang semula hanya menjalankan sistem bank konvensional juga Menjalankan sistem perbankan syariah. Mendasarkan teori adopsi inovasi, Everet M Roger (1995) pola adopsi inovasi masyarakat berkembang dari sedikit kemudian menyebar menjadi banyak, melalui suatu tahapan berupa innovator, early adopter, early majority, late majority. Pola analisis ini sudah banyak digunakan untuk menjawab proses pengadopsian berbagai inovasi misalnya penggunaan teknologi pertanian baru bagi petani, penerimaan teknologi komputer dalam proses pembelajaran, dan adopsi inovasi pada pemerintahan.

Penelitian tentang adopsi UKM terhadap perbankan Syariah dipandang penting mengingat, karakteristik perbankan Syariah yang tidak didasarkan atas bunga sehingga bisa meminimalisir resiko usaha UKM, serta menjadi alternatif pembiayaan bagi mereka. Penelitian ini diharapkan dapat menguji faktor apa saja yang mendorong UKM di wilayah Surakarta menggunakan bank syariah sebagai alternatif pendanaan, maupun investasi, bagaimana tingkat penerimaan (level adopsi) UKM terhadap perbankan syariah, dan bagaimana keterkaitan antara karakteristik UKM dengan tingkat pengadopsian perbankan syariah. Dengan menganalisis faktor yang mendorong UKM untuk mengadopsi dan tidak mengadopsi maka sistem perbankan, pengambil kebijakan khususnya Perbankan syariah dapat memperbaiki kebijakan yang lebih pro kepada UKM.

Di Surakarta, UKM merupakan kota di mana mereka merupakan penggerak dari perekonomian masyarakat (Soebagiyo, 2008). Data IKM Surakarta pada tahun 2007 mencapai 80 persen jumlah usaha dengan kontribusi penyerapan tenaga kerja mencapai lebih dari 95 persen (lihat Tabel 1). Dengan jumlah yang cukup besar, maka mereka adalah potensi pasar yang sangat menarik bagi pembiayaan melalui sistem perbankan syariah.

\section{METODE PENELITIAN}

\section{Populasi dan Sampel}

Populasi dalam penelitian ini adalah UKM yang ada di Surakarta. Sampel yang digunakan dalam penelitian ini adalah UKM yang ada dalam sentra industri dan perdagangan di Surakarta seperti Laweyan, Bibis, Pasar Klewer, Pasar Kliwon dan UKM di jalan Slamet Riyadi. Teknik pengambilan sampel yang digunakan adalah dengan simple random sampling. Sebanyak 80 responden diperoleh sebagai sampel penelitian. Setelah diseleksi lebih lanjut hanya 62 jumlah responden yang benar-benar mewakili tujuan penelitian dan memenuhi syarat penelitian. Untuk menjamin bahwa sampel tersebut benar-benar sesuai dengan tujuan penelitian, maka responden yang digunakan adalah pemilik dari UKM yang bersangkutan. Dari jumlah tersebut 26 responden adalah nasabah bank syariah dan sebanyak 36 adalah non nasabah.

\section{Data dan Teknik Pengumpulan Data}

Dalam penelitian ini, data yang dibutuhkan adalah data personal responden, data perusahaan, serta data tentang sikap dan preferensi responden terhadap produk, dan layanan bank syariah. Data personal seperti: umur, jenis kelain, agama, pendapatan, pendidikan, alamat;

Tabel 1. Perkembangan IKM Surakarta

\begin{tabular}{llrccc}
\hline No & Uraian & $\begin{array}{c}\text { Tenaga } \\
\text { Kerja }\end{array}$ & $\begin{array}{c}\text { Nilai } \\
\text { Investasi }\end{array}$ & $\begin{array}{c}\text { Nilai } \\
\text { Produksi }\end{array}$ & $\begin{array}{c}\text { Jumlah Unit } \\
\text { Usaha }\end{array}$ \\
\hline 1 & Industri kecil & 24.954 & 57.895 .790 & 4.239 .889 .800 & 1.061 \\
2 & Industri Menengah & 7.560 & 45.870 .748 & 1.127 .798 .350 & 85 \\
3 & Industri Besar & 10.680 & 297.795 .960 & 1.017 .089 .000 & 41 \\
4 & Non Formal & 12.055 & 15.071 .040 & 1.592 .397 .420 & 4.070 \\
5 & Jumlah & 55.177 & 416.633 .538 & 7.977 .174 .570 & 5.257 \\
\hline
\end{tabular}

Sumber: Disperindag Surakarta, 2006. 
data perusahaan yang meliputi jenis usaha, bidang usaha, omset, jumlah karyawan, dan status nasabah. Untuk mendapatkan data peneitian, dilakukan dengan penyebaran angket atau kuesioner. Rancangan kuesioner adalah self administrated questionnaire. Namun demikian sebagian dari pengisian kuesioner dilakukan dengan wawancara, sebagian lagi dilakukan dengan di isi sendiri oleh responden. Dari 80 data yang diperoleh, sejumlah 8 data tidak digunakan karena pengisi kuesioner adalah karyawan perusahaan sehingga dianggap tidak sah, dan 10 data kuesioner tidak terisi lengkap.

\section{Uji Validitas dan Uji Reliabilitas}

Kuesioner dikembangkan dari variabel-variabel yang diajukan oleh Everret M Roger, tentang difusi-inovasi yang dimodifikasikan disesuaikan dengan subyek penelitian. Untuk menguji validititas instrumen dilakukan uji content validity, dimana peneliti membuat instrumen kemudian diujikan kepada sejumlah responden sebagai pilot test. Untuk keperluan ini sebanyak 15 responden digunakan sebagai pilot tes. Responden yang digunakan adalah dosen di Fakultas Ekonomi Universitas Muhammadiyah Surakarta. Hasil dari pilot test di Universitas $\mathrm{Mu}-$ hammadiyah Surakarta, dilakukan perbaikan instrumen atas masukan-masukan mereka.

Pengujian instrumen melalui uji reliabilitas dilakukan untuk melihat keandalan suatu alat ukur.

Tabel 2. Uji Reliabillitas Variabel

\begin{tabular}{clc}
\hline No & Variabel & Alpha Cronbach \\
\hline $\mathbf{1}$ & Keuntungan Relatif & 0,82 \\
$\mathbf{2}$ & Kompatibilitas & 0,623 \\
$\mathbf{3}$ & Kompleksitas & 0,633 \\
$\mathbf{4}$ & Trialibitas & 0,746 \\
$\mathbf{5}$ & Observabilitas & 0,592 \\
\hline
\end{tabular}

Pengujian dilakukan terhadap lima variabel penelitian yaitu X1 (keuntungan relative), X2 (kompatibilitas), X3 (kompleksitas), X4 (trialibilitas) dan X5 (Observalibilitas). Hasil pengujian memperlihatkan bahwa secara umum bahwa instrumen tersebut handal. Hal ini dapat dilihat dari nilai Cronbach Alpha yang hampir semuanya di atas 0,6 (kecuali X5).

\section{Variabel Penelitian}

(1) Variabel Dependen dan Pengukurannnya. Adopsi inovasi merupakan suatu proses mental pada diri seseorang sejak ia mengenal inovasi sampai memutuskan untuk mengadopsinya setelah menerima inovasi.

(2) Variabel Independen dan pengukurannya: (a) Keuntungan relatif: adalah sejumlah keuntungan yang diterima oleh konsumen dari suatu hasil inovasi dibandingkan keuntungan yang diperoleh sistem lama; (b) Kompatibilitas: kesesuaian antara teknologi lama (existing technology) dengan teknologi baru (introduction technology). kompatibilitas mempunyai keterkaitan dengan nilai sosial budaya, kepercayaan, gagasan yang dikenalkan sebelumnya, dan keperluan yang dirasakan oleh individu; (c) Kompleksitas adalah mudah tidaknya inovasi dapat dipraktekkan oleh pemakai; (d) Trialibilitas adalah tingkat dimana inovasi mungkin akan dicobakan pada wilayah yang terbatas; (e) Observabilitas (penampakan inovasi) merupakan tingkat dimana hasil dari inovasi terlihat oleh pihak lain.

Dalam penelitian ini digunakan analisis Regresi berganda dan Chi-Square. Analisis Regresi berganda digunakan untuk melihat pengaruh model faktor Adopsi-inovasi yang disampaikan oleh Roger terhadap keputusan mengadopsi bank syariah, oleh UKM di Surakarta. Analisis Chi-Square digunakan untuk menguji perbedaan preferensi nasabah dan non nasabah terhadap atribut produk bank syariah, serta menguji keterkaitan karakteristik UKM terhadap pilihan adopsi bank syariah.

Berdasarkan variabel-variabel yang disebutkan di atas, peneliti melakukan analisis regresi dengan model sebagai berikut:

$Y=a+\beta X 1+X 2+X 3+X 4+X 5+e$

dimana: Variabel dependen Y adalah keputusan mengadopsi bank syariah. Variabel independen $\mathrm{X} 1$ adalah keuntungan relatif, $\mathrm{X} 2$ adalah kompatibilitas, X3 adalah kompleksitas, $\mathrm{X} 4$ adalah trialibilitas, $\mathrm{X} 5$ adalah observabilitas, dan e adalah variabel pengganggu. 


\section{Uji Koefisien Determinasi}

Uji Koefisien Determinasi (R2) pada intinya adalah mengukur seberapa jauh kemampuan model dalam menerangkan variasi pada variabel dependen. Nilai koefisien determinasi adalah antara nol dan satu. Nilai R2 yang kecil mengindikasikan kemampuan yang rendah dari keseluruhan variabel independen dalam menjelaskan variasi yang terdapat dalam variabel dependen. Nilai yang mendekati satu, berarti variabel independennya mampu menjelaskan variasi yang terdapat dalam variabel dependen secara sempurna.

\section{Uji Signifikansi Simultan (Uji F Statistik)}

Uji signifikansi simultan (Uji F Statistik). Menunjukkan seberapa fit besar model yang digunakan. Untuk melakukan pengujian tersebut dilakukan dengan membandingkan $\mathrm{F}$ hitung dengan $\mathrm{F}$ tabel. Jika $\mathrm{F}$ hitung lebih besar dari $\mathrm{F}$ tabel, dengan tingkat kepercayaan 95 persen ( $p$ Value $<0,05$ ), mempunyai arti model tersebut fit dan dapat diinterpretasikan.

\section{Uji Signifikansi Parameter Individual (uji t statistik)}

Uji Signifikansi Parameter Individual (uji t statistik). Uji t statistik menunjukkan seberapa jauh pengaruh masing-masing variabel penjelas secara individual dalam menerangkan variasi dalam variabel dependen. Uji $\mathrm{t}$ statistic yang digunakan memakai tingkat kepercayaan sebesar 95 persen.

Sedangkan untuk menguji untuk menguji ada tidaknya perbedaan karakteristik UKM, serta perbedaan preferensi nasabah non nasabah terhadap atribut produk bank syariah digunakan analisis Cross tabulation dan ChiSquare. Adapun faktor yang diuji dari karakteristik UKM adalah: (1) latar belakang agama pemilik usaha, (2) latar belakang pendidikan pemilik usaha (3) jumlah asset, dan (4) jenis badan usaha. Sedangkan atribut produk yang diuji meliputi: sistem bunga, sistem bagi hasil, tingkat resiko, biaya dan fasilitas. Adapun untuk analisis Chi-Square, dengan Cross tabulation model matematisnya dapat dijabarkan sebagai berikut:
$C S=\sum \frac{(O i j-E i j)^{2}}{E_{i j}}$

dimana: Oij adalah Nilai sel yang diamati (observed), Eij adalah Nilai sel yang di harapkan, $\mathbf{r}$ adalah baris (row), $\mathbf{c}$ adalah kolom (column), Eij=Pr $\times$ Pc $\times n$

\section{HASIL DAN PEMBAHASAN}

\section{Deskripsi Data}

Data penelitian terbagi dalam beberapa informasi demografis responden yaitu: jenis kelamin, pendidikan, agama, umur, dapat dilihat dalam Tabel 3.

Tabel 3. Deskripsi Responden

\begin{tabular}{lr}
\hline Jenis Kelamin & \\
Laki-laki & 42 \\
Perempuan & 19 \\
Jumlah & $\mathbf{6 2}$ \\
Status & \\
Nasabah & 26 \\
Non-Nasabah & 36 \\
Jumlah & 62 \\
Pendidikan: & \\
SMP & 3 \\
SMA & 26 \\
D3 & 4 \\
S1 & 23 \\
S2 & 5 \\
Jumlah & $\mathbf{6 2}$ \\
Agama & \\
Islam & 57 \\
Kristen & 3 \\
Katolik & 2 \\
Jumlah & $\mathbf{6 2}$ \\
Bidang Usaha & \\
Pertanian & 4 \\
Perdagangan & 31 \\
Konstruksi & 2 \\
Komunikasi & \\
Jasa & 9 \\
Industri & 12 \\
Lainya & 4 \\
Jumlah & $\mathbf{6 2}$ \\
Umur & 7 \\
<25 & 37 \\
25-40 & $\mathbf{6 2}$ \\
40> & \\
Jumlah & \\
\hline &
\end{tabular}


Informasi personal lainnya berupa status nasabah. Adapun informasi tentang perusahaan, berupa jenis bidang usaha. Berdasarkan jenis kelamin, sebanyak 42 responden berjenis kelamin laki-laki, dan 19 responden berjenis kelamin perempuan. Apabila ditilik dari latar belakang pendidikan, maka mayoritas responden adalah berpendidikan SMA, sebanyak 26 nasabah, kemudian berpendidikan S1 sejumlah 23, dan sisanya berpendidikan D3 sejumlah 5 orang dan sebanyak 5 orang lulusan Sarjana strata 2. Berdasarkan agama responden, ada tiga jenis agama yang dianut oleh responden yaitu Islam, sebanyak 57 orang, Kristen 3 orang dan Katolik berjumlah 2 orang. Hampir 100 persen responden yang menjadi nasabah Bank Syariah memeluk agama Islam.

Berdasarkan latar belakang responden, terlihat bahwa responden yang digunakan mempunyai kecenderungan mampu menjawab pertanyaan dengan baik, sekalipun belum tentu mereka memahami pemahaman yang baik terhadap sistem perbankan syariah. Hal ini dapat dikonfirmasi dari latar belakang mereka yang berpendidikan di atas SMA lebih banyak dibandingkan berpendidikan SMA ke bawah.

\section{Produk}

Secara umum nasabah mempunyai preferensi yang cukup beragam terhadap produk yang disediakan oleh bank syariah. Hal ini dapat dilihat dari sebaran produk yang nasabah pilih. Namun demikian produk yang cukup diminati oleh nasabah adalah mudarobah dan al-musyarokah, dimana sebanyak 23 persen dari total nasabah menggunakan produk tersebut. Produk Istisna, Murobahah, dan Wadiah menempati posisi berikutnya dengan jumlah 12 persen dari total nasabah yang dijadikan responden.

Dalam bisnis syariah terdapat lima prinsip aktivitas bisnis yang mendasari perbankan syariah yaitu: simpanan, bagi hasil, pengambilan keuntungan, sewa, pengambilan fee, dan kebajikan (Qard Hasan). Kegiatan Mudorabah, Musyarokah adalah aktivitas yang termasuk bagi hasil, adapun wadiah adalah simpanan. Sedangkan kegiatan Istisna, dan salam adalah aktivitas yang termasuk dalam aktivitas pembiayaan jual beli (50 persen), dapat dilihat dalam Tabel 4.
Tabel 4. Deskripsi Penggunaan Produk

\begin{tabular}{lcc}
\hline Produk & Jumlah & Persentase \\
\hline Istisna & 4 & $15 \%$ \\
Mudarobah & 6 & $23 \%$ \\
Ijaroh & 2 & $8 \%$ \\
Murobahah & 3 & $12 \%$ \\
Wadiah & 3 & $12 \%$ \\
Al-Musyarokah & 6 & $23 \%$ \\
Lainnya & 2 & $8 \%$ \\
\hline
\end{tabular}

Dari hasil tabulasi data memperlihatkan adanya kecenderungan nasabah paling banyak melakukan aktivitas pembiayaan (jual-beli). Hal ini dapat terlihat dari gabungan produk Ijaroh, Istisna, dan Murobahah yang secara total mencapai 50 persen dari total aktivitas bisnis yang dilakukan melalui bank syariah. Berikutnya adalah kegiatan pendanaan bagi hasil yang tercermin dari produk Mudarobah dan Al-Musyarokah yang mencapai 46 persen. Dari sini kita melihat angka yang tidak jauh berbeda antara kegiatan bagi hasil dan jual beli. Hal ini memperlihatkan bahwa penggunaan nasabah untuk kegiatan produktif dan konsumtif hampir berimbang.

\section{Kecenderungan Mengadopsi}

Berdasarkan hasil penelitian, sebanyak hampir 41 persen (26 dari 62) responden yang disurvei menyatakan telah menjadi nasabah bank syariah dan sisanya sebanyak 59 persen belum menjadi nasabah bank syariah. Sekilas angka ini sangat tinggi dibandingkan dengan rata-rata nasional yang kurang dari 10 persen. Namun demikian apabila data yang ditampilkan berasal dari keseluruhan kuesioner (80 kuesioner) yang berhasil diperoleh dalam masa penelitian, maka angka tersebut semakin turun dengan jumlah responden yang menjadi nasabah hanya berkisar 20 persen (Lihat Tabel 5).

Tabel 5. Distribusi Data NasabahNon Nasabah

\begin{tabular}{lll}
\hline Nasabah & 26 & $41 \%$ \\
Non Nasabah & 36 & $59 \%$ \\
\hline
\end{tabular}

Adapun untuk kategori non nasabah, tingkat keinginan mereka untuk menjadi nasabah 
nal bank syariah. Sebanyak 26 persen responden merasa belum mengenal bank syariah. Hal ini menandakan sosialisasi dari lembaga bank syariah masih kurang, sekalipun mayoritas responden adalah muslim (92 persen).

Tabel 8. Alasan Tidak Mengadopsi

\begin{tabular}{clc}
\hline & Alasan tidak berminat & Persentase \\
\hline 1 & Belum mengenal produk & $26 \%$ \\
& syariah & \\
2 & Istilah produk yang rumit & $11 \%$ \\
3 & Fasilitas tidak lengkap & $23 \%$ \\
4 & Jumlah kantor cabang & $18 \%$ \\
& sedikit & $6 \%$ \\
5 & Pelayanan & $10 \%$ \\
6 & Beban anggaran & $3 \%$ \\
7 & Lainnya & $3 \%$ \\
8 & Lainnya & $100 \%$ \\
\hline
\end{tabular}

Fasilitas yang kurang lengkap (23 persen) menjadi alasan berikutnya. Di sisi lain selain respon belum merasa cukup mengenal bank syariah, istilah-istilah Arab yang digunakan dalam sistem perbankan syariah, menyulitkan mereka untuk memahami sistem ini. Jumlah kantor cabang yang sedikit membuat enggan UKM menjadi nasabah di bank syariah.

Pandangan di atas setidaknya dapat dikonfirmasi dengan data tentang pandangan responden terhadap halal dan haramnya bunga bank konvensional. Dari kalangan responden non nasabah bank syariah diperoleh informasi bahwa sebanyak 38 persen responden menyatakan bunga bank konvensional sebagai boleh, 52 persen menyatakan subhat (meragukan), dan hanya 10 persen responden yang menyatakan bahwa bunga adalah haram. Dari sisi ini dapat dianalisis bahwa sifat bunga bank yang meragukan dan haram boleh jadi menjadi pendorong bagi UKM (pengusaha) untuk menjadi nasabah bank syariah, karena pandangan yang membolehkan hanya 38 persen dibandingkan dengan yang meragukan dan haram sebanyak 52 persen dan 10 persen. Namun demikian mayoritas responden yang memandang bunga bank sebagai subhat (meragukan) sebagai sinyal bahwa mereka tidak benar-benar sepenuhnya meninggalkan bank konvensional.

Data pada Tabel 9 memperlihatkan adanya perbedaan pandangan nasabah yang menjadi nasabah dan non nasabah. Pada responden yang telah menjadi nasabah bank syariah, persentase responden yang memandang bunga bank sebagai haram sebanyak 19 persen, lebih tinggi dibandingkan responden yang belum menjadi nasabah bank syariah sebanyak 10 persen. Adapun responden dari kalangan non nasabah yang memandang suku bunga sebagai boleh lebih tinggi persentasenya (38 persen) dibandingkan nasabah (31 persen).

Tabel 9. Pandangan Responden terhadap Suku Bunga Bank Konvensional

\begin{tabular}{lcc}
\hline & Nasabah & Non Nasabah \\
\hline Boleh & $31 \%$ & $38 \%$ \\
Sub'hat & 50 & 52 \\
Haram & 19 & 10 \\
\hline
\end{tabular}

Ini memperlihatkan bahwa pandangan individu tentang halal-haramnya suku bunga bank konvensional dapat mempengaruhi pilihan mereka untuk mengadopsi bank syariah. Namun demikian hasil pengujian statistik melalui uji chi-square, tidak ada perbedaan yang signifikan antara kategori nasabah dan non nasabah, terhadap bungan bank.

Hal ini sejalan dengan temuan peneliti sebelumnya (Ahyani, 2009), dimana terdapat masyarakat yang kurang dapat menentukan sikap terhadap halal-haramnya bunga perbankan yang dipicu oleh persepsi toleransi terhadap setiap nilai perbedaan yang ada.

Dari sisi manfaat bagi hasil perbedaan terlihat cukup mencolok. Sebanyak 54 persen, responden yang berasal dari nasabah menyatakan bahwa sistem bagi hasil yang mereka terima adalah adil. Hal ini berbeda secara nyata dengan responden yang berasal dari non nasabah yang memandang bahwa sistem bagi hasil di Bank Muamalah adalah adil hanya 14 persen. Tidak ada nasabah dari kalangan nasabah yang memandang sistem bagi hasil tidak adil (0 persen), sementara itu dari kalangan non nasabah, sebanyak 14 persen dari mereka menyatakan sistem bagi hasil tidak adil (lihat Tabel 10). 
kan terdapat keputusan untuk mengadopsi bank syariah.

Berdasarkan hasil regresi, dapat dituliskan dengan model sebagai berikut:

$Y=1,894-0,077 X_{1}+0,23 X_{2}-0,04 X_{3}+0,03 X_{4}-$ $0,05 X_{5}$

Secara umum, apabila melihat dari arah masing-masing variabel independen terhadap variabel dependennya, model kurang mampu menjelaskan dengan secara teori dengan jelas. Variabel keuntungan relatif, kompleksitas, dan observabilitas mempunyai arah yang negatif. Variabel kompleksitas memang mampu mengkonfirmasi dengan arah yang benar, karena semakin kompleks produk baru untuk bisa dievaluasi oleh calon pelanggan semakin enggan pelanggan untuk mengadopsi produk baru atau inovasi baru dalam masyarakat. Namun untuk keuntungan relatif, arah yang berkebalikan memberikan interpretasi yang kurang sesuai dengan teori. Dalam teori, apabila konsumen semakin banyak memperoleh keuntungan relatif dari produk baru terhadap produk lamanya, maka semakin mudah mereka untuk mengadopsi inovasi baru. Demikian halnya dengan variabel observabilitas, dimana semakin mudah untuk diobservasi, semakin mudah mereka menerima inovasi baru (Lihat Tabel 14).

\section{Karakteristik UKM dan Adopsi Bank Syariah}

Karakteristik UKM dapat dilihat dari beberapa unsur di antaranya: bidang usaha yang dite- kuni, ukuran perusahaan (jumlah omset, jumlah asset, jumlah karyawan), jumlah pendapatan yang diperoleh dan lama usaha. Namun dalam penelitian ini, peneliti hanya memperoleh data tentang jenis usaha, sementara data lainnya seperti pendapatan dan umur perusahaan tidak dapat dikonfirmasi, karena data tidak lengkap.

Dalam Tabel 15, data sebaran bidang usaha dari responden baik itu berstatus nasabah dan non nasabah bank syariah. Responden terbanyak berasal dari bidang usaha perdagangan dengan persentase sebesar 50 persen dari total responden yang digunakan, diikuti oleh bidang jasa dengan 23 persen, dan industri (manufaktur) sebesar 12 persen.

Apabila dikaji lebih lanjut dari latar belakang jenis bidang usaha UKM terhadap adopsi bank syariah dapat dilihat bahwa UKM yang bergerak dalam bidang usaha komunikasi dan pertanian menempati urutan teratas dengan persentase sebesar 100 persen dan 50 persen. Namun demikian karena sampel yang digunakan untuk unit ini sangatlah kecil maka informasi tersebut bisa dikesampingkan (Tabel 16).

Hal yang perlu diperhatikan adalah proporsi UKM bidang usaha jasa yang telah mengadopsi Bank syariah adalah sebesar 46 persen. Apabila jumlah responden yang menjadi nasabah dan non nasabah diperbandingkan maka angka ini menjadi lebih besar yaitu 86 persen. Berikutnya adalah UKM yang bergerak dalam bidang usaha perdagangan dimana UKM yang telah mengadopsi bank syariah sebesar 42 persen. Apabila diperbandingkan antara pro-

Tabel 14. Hasil Uji Regresi

\begin{tabular}{|c|c|c|c|c|c|c|}
\hline Model & $\mathbf{R}$ & R Square & \multicolumn{2}{|c|}{ Adjusted R Square } & F & \\
\hline 1 & 0,990 & 0,980 & \multicolumn{2}{|c|}{0,977} & 386,724 & 0, \\
\hline \multicolumn{2}{|r|}{ Model 1} & $\begin{array}{r}\text { Unsta } \\
\mathrm{Co}\end{array}$ & $\begin{array}{l}\text { hdardized } \\
\text { fficient } \\
\text { B }\end{array}$ & $\mathrm{t}$ & Sig & \\
\hline \multicolumn{2}{|r|}{ Konstan } & & 1,894 & 18,567 & 0,000 & \\
\hline \multicolumn{2}{|r|}{ Krelf } & & - 077 & $-10,994$ & 0,000 & \\
\hline \multicolumn{2}{|r|}{ Kompatible } & & ,023 & 4,433 & 0,000 & \\
\hline \multicolumn{2}{|r|}{ Kompleks } & & $-0,04$ &,- 397 & 0,693 & \\
\hline \multicolumn{2}{|r|}{ Trial } & & 0,03 & 0,370 & 0,679 & \\
\hline \multicolumn{2}{|r|}{ Observab } & &,- 005 &,- 417 & 0,679 & \\
\hline
\end{tabular}




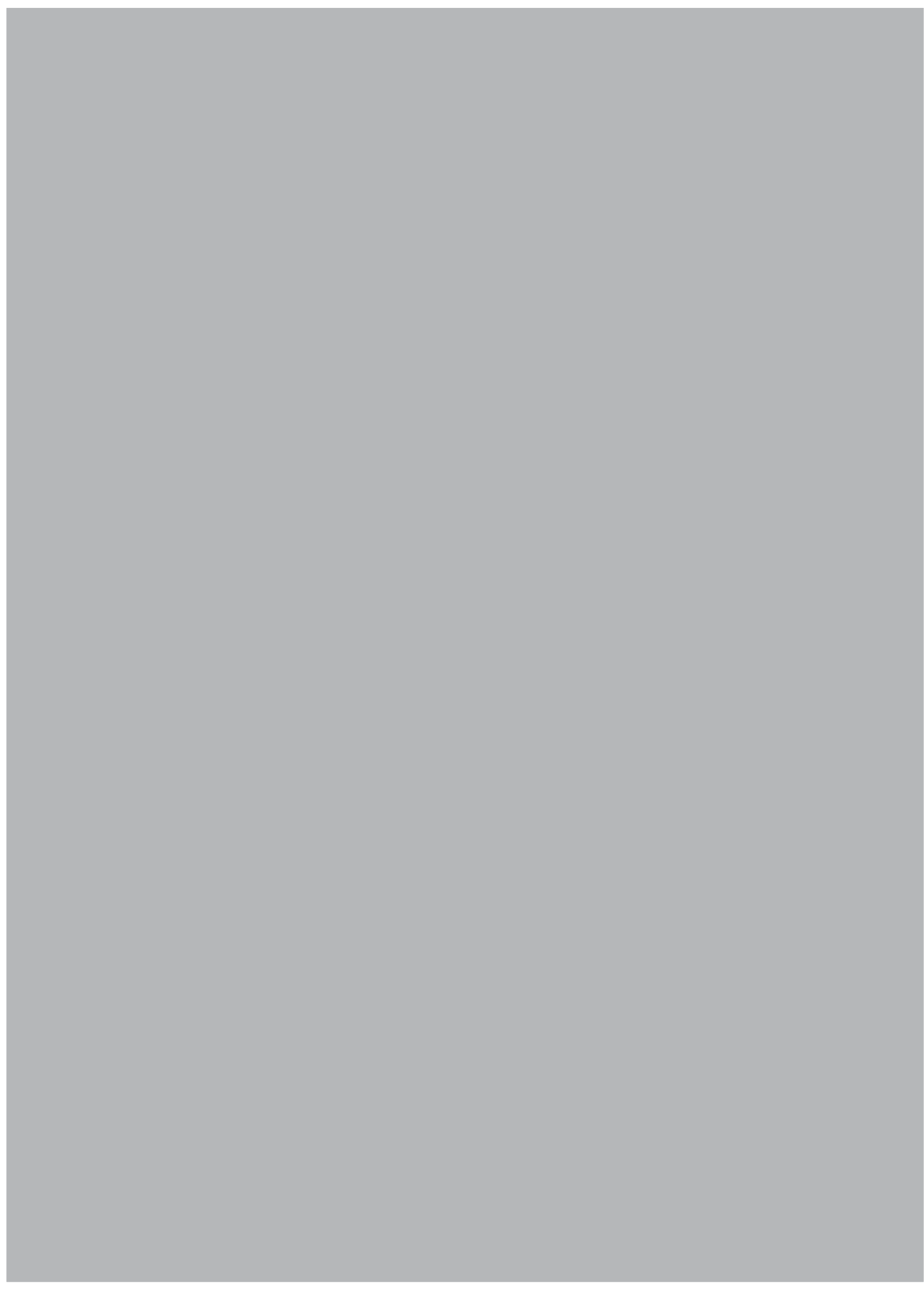


untuk menggunakan jasa perbankan tidaklah semata-mata di dorong oleh ke-haram-an sistem bunga pada bank konvensional. Apabila ini dikonfirmasikan dengan penelitian sebelumnya, hal ini sejalan dengan temuan dari penelitian yang dilakukan oleh Irbid dan Zarka (2001) memberikan kesimpulan bahwa faktor yang mendorong nasabah memilih bank konvensional dan bank syariah, didasarkan kepada motif keagamaan dan non keagamaan.

Di sisi lain masyarakat UKM yang menjadi nasabah bank syariah merasakan manfaat bagi hasil sebagai sesuatu yang signifikan, dibandingkan atribut produk yang lain pada bank syariah seperti biaya, resiko, dan fasilitas. Biaya, sistem bagi hasil, dan resiko adalah suatu aspek yang berhubungan erat satu sama lain. Biaya yang tinggi bagi nasabah dalam meminjam akan memberikan imbal yang tinggi bagi nasabah penabung ataupun deposito (mudarobah).

Dari hasil survei tentang alasan ketidakmauan UKM untuk mengadopsi bank Syariah dapat diimplikasikan tentang proses difusi informasi bank syariah selama ini di Surakarta. Proses difusi atau penyebaran informasi bank syariah kepada UKM berjalan lambat, hal ini dapat dilihat dari keengganan UKM untuk mengadopsi bank syariah karena ketidaktahuan mereka terhadap sistem operasi dan produk dari bank syariah. Sebanyak 37 persen enggan beralih karena ketidaktahuan akan sistem operasi dan produk bank syariah. Padahal proses adopsi inovasi akan terwujud apabila terdapat cukup tersebarnya informasi kepada masyarakat.

Secara keseluruhan hasil temuan penelitian memperlihatkan bahwa tidak ada perbedaan persepsi UKM yang menjadi nasabah ataupun non nasabah terhadap sistem bunga, biaya bank, dan tingkat resiko. Adapun terhadap sistem bagi hasil, terdapat perbedaan pendapat antara nasabah dan non nasabah. Bagi responden yang telah menjadi nasabah, persepsi adil jauh lebih (54 persen) dibandingkan non nasabah (14 persen). Ini artinya responden yang telah menjadi nasabah lebih merasakan sistem bagi hasil dibandingkan yang belum menjadi nasabah.

Dari hasil pengujian regresi linier berganda didapatkan informasi bahwa hanya variabel keuntungan relatif (X1), dan kompabitilitas (X2) yang secara signifikan berpengaruh terhadap adopsi bank syariah. Sedangkan variabel kompleksitas, trialibilitas, dan observabilitas tidak berpengaruh secara signifikan terdapat keputusan untuk mengadopsi bank syariah. Dalam kontek perbankan syariah, suatu indvidu atau anggota masyarakat akan mengadopsi perbankan syariah manakala sistem ini memberikan keuntungan yang nyata dibandingkan sistem konvensional.

Secara umum keuntungan relatif bagi nasabah (debitur-deposan) bank syariah dapat dibagi dalam dua aspek, yaitu aspek keagamaan, dan aspek ekonomis-bisnis (duniawi). Dari sisi keagamaan, jaminan halal, dan sistem bagi hasil adalah keuntungan relatif yang jelas akan diterima oleh konsumen bank syariah. Dalam penelitian ini, telah dikonfirmasi bahwa nasabah mendapatkan keuntungan relatif berupa bagi hasil yang menguntungkan. Dari aspek kompatibilitas apabila dibandingkan antara bank konvensional dan bank syariah, produk yang ditawarkan tidak jauh berbeda. Pada bank syariah juga ditemukan produk yang ditawarkan pada bank konvensional seperti tabungan (tabungan mudhorobah), deposito (deposito mudharobah), jasa penitipan (wadiah), pembiayaan (musyarokah), sewa beli (al-ijarah). Yang membedakan adalah prinsip-prinsip yang melandasi operasional banking-nya.

Pada bagian akhir dari penelitian ini peneliti tidak dapat mengkonfirmasi hubungan antara keputusan mengadopsi dengan karakteristik UKM karena kurang cukupnya data penelitian. Namun dari hasil pengolahan data yang ada terlihat tidak ada keterkaitan antara karakteristik UKM dengan keputusan untuk mengadopsi bank syariah. Hal ini sangat munkin terjadi karena UKM adalah jenis organisasi usaha, dimana keputusan dari pemilik sangatlah dominan terhadap keputusan bisnis keyakinan pribadi lebih mendasari keputusan perusahaan. Termasuk dalam hal ini, adalah keyakinan pribadi tentang halal haram sistem bunga bank konvensional yang pada akhirnya mungkin berpengaruh terhadap pilihan dalam memilih bank. 


\section{SIMPULAN}

UKM di Surakarta mempunyai kecenderungan untuk mengadopsi bank Syariah, hal ini dapat dilihat dari jumlah persentase responden yang menyatakan ingin mengadopsi bank syariah lebih banyak dibandingkan dengan responden yang tidak berkeinginan untuk mengadopsi bank syariah.Namun kecenderungan yang lain, adalah hanya sedikit dari UKM yang benarbenar akan menjadi pelanggan bank syariah dan meninggalkan bank konvensional sebagai sumber pendanaan dan alternatif penyimpanan surplus pendanaan.

Hasil temuan penelitian memperlihatkan bahwa tidak ada perbedaan persepsi UKM yang menjadi nasabah ataupun non nasabah terhadap elemen-elemen sistem bunga, biaya bank, dan tingkat resiko. Adapun terhadap sistem bagi hasil, terdapat perbedaan pendapat antara nasabah dan non nasabah.

Dari hasil pengujian regresi linier berganda diperoleh informasi bahwa hanya variabel keuntungan relatif (X1), dan kompabitilitas (X2) yang secara signifikan berpengaruh terhadap adopsi bank syariah. Sedangkan variabel kompleksitas, trialibilitas, dan observabilitas tidak berpengaruh secara signifikan terdapat keputusan untuk mengadopsi bank syariah.

Keterkaitan antara karakteristik UKM dengan keputusan untuk mengadopsi bank syariah tidak dapat dikonfirmasi.

\section{Ucapan Terima Kasih}

Peneliti mengucapkan terima kasih kepada Dr. Harun, M.Hum selaku kepala LPPM, dan Prof. Dr. Markhamah, M.Hum yang telah memberikan kesempatan untuk melakukan penelitian ini serta Drs. Farid Wajdi, selaku reviewer, dan teman-teman seprofesi seperti Anton Agus Setiawan, Jati Waskito, dan M. Sholahudin, yang telah banyak memberikan kontribusi bagi penulis dalam hal metode penelitian.

\section{DAFTAR PUSTAKA}

Achyani, Fatchan dan Sugiyanto, Eko. 2009. Identifikasi terhadap Persepsi Mahasiswa ten- tang keberadaan Bank Syariah di Solo. Penelitian Reguler. Surakarta: LPPM UMS.

Ancok, Djamaludin. 1995. Tehnik Penyusunan Skala Pengukur. Pusat Penelitian Kependudukan. Universitas Gadjah Mada. Yogyakarta.

Antonio, M. Syafei. 1999. Bank Syariah: Suatu Pengenalan Umum. Jakarta: Tazkia Institute dan Bank Indonesia.

Antonio, M.Syafei. 1999. Bank Syariah: Wacana Ulama dan Cendekiawan. Jakarta: Tazkia Institute dan Bank Indonesia.

Bank Indonesia. 2000. Informasi Mengenai Peraturan Bank Indonesia Bagi Bank Umum Berdasarkan Prinsip Syariah.

Bank Indonesia. 2000. Petunjuk Pelaksanaan Pembukaan Bank Syariah.

Gibson L, James, Ivancevic, John M., Donelly, James H. 1987. Organisasi: Perilaku, Struktur dan Proses. Jakarta: Penerbit Erlangga.

Karim, Adiwarman. 2004. Prospek dan Tantangan Ekonomi Syariah Indonesia. Publikasi Internet.

Kaynak, E and Yavas. 1985. Segmenting the Banking Market by Account Usage: An Empirical Investigation. Journal of Professional Services Marketing. Vol.1 No.1/ 2.

Lemlit Undip. 2000). Penelitian Potensi, Preferensi, dan Perilaku Masyarakat terhadap Bank Syariah di Wilayah Jawa Tengah dan DIY.

Metawa, Saad A, \& Mohammed Almossawi. 1998. Banking Behavior of Islamic Bank customers: perspectives and implications. International Journal Behavior. Vol.XI: 131152, 1998.

Pindick, Robert S., and Rubenfield, Daniel. 1981. Econometric Models and Economic Forecast. International Student Edition. Mc Graw-Hill.

Presley, John R and Hummayon Dar. 2001. Attitudes Towards Islamic Finance: An Update of Empirical Evidence. 7th Inten- 
sive Orientation Courses: Islamic Economic. Banking \& Finance. Leicester. UK.

Rachma, Malia. 2003. Peluang dan Strategi Pengembangan. Publikasi Internet.

Rogers, E. M. 2004. Diffusion of Innovations. New York: Free Press.

Soebagyo, Daryono dan Wahyudi. 2008. Analisis Kompetensi Keunggulan Daerah pada Produk Batik Tulis dan Cap di Dati
II kota Surakarta. Jurnal Ekonomi Pembangunan FE UMS. Vol. 9 No 2. Desember. Surakarta: BPPE FE UMS

Wijayanti, Tri, Pramuka B.A dan Astogini, D., 2004. Faktor-faktor yang Dipertimbangkan Masyarakat terhadap Pemilihan Sistem Perbankan Syariah. SMART: Vol. 1 No. 1 Januari 2004: (p.29-44). 